\title{
Output and employment in the financial sector
}

\section{SUMMARY}

This article describes how the quarterly output of the financial services sector is measured in the National Accounts. Then at a sub-sector level, an analysis of recent employment and output trends is presented to describe the impact of the current economic downturn on the activity of the sector. The sub-sectors analysed include banks, building societies, investment trusts, life insurance, non-life insurance and pension funding.
T his article examines how the impact of the credit crisis has been captured by quarterly output measures and corresponding measures of employment. It discusses, on a sub-sector level, whether the output indicators have captured the real effects of the crisis. Consideration will also be given as to how well these indicators have captured financial innovations.

The first part of the article examines the broad structure of the financial sector based on the Standard Industrial Classification (SIC). The rest of the article consists of an analysis of the relationship between trends and movements in these indicators and the corresponding labour market data. This approach will provide initial findings on the quality of output indicators, with respect to expected movements and their coherence with other measures of financial sector activity.

Although the sample size of the Labour Force Survey (LFS) is likely to be small at this level of detail for some sectors it is still likely to give a reasonable indicator for broad trends over the period. Though not strictly the preferred employment measure for industrial classification (Workforce Jobs (WFJ) being the recommended series) it is the best source of employment data at the level of detail required. In a sector where output coverage is incomplete and activity subject to constant innovation it is likely that LFS employment estimates may offer a better picture of the underlying position of this industry with which to consider the reliability of the output data.

The analysis shows that direct and indirect output indicators for banks and building societies combined have continued to grow, despite the onset of the crisis. Reasons to support this interpretation are discussed in detail later, although it is worth noting here that restrictions in the supply of credit and increases in the price of arrangements fees have all played their part.

Output indicators for the life, nonlife and pension industries have either remained stable or declined slowly, although they do not appear to have been impacted adversely by the credit shock.

Despite the developments in activity indicators, the majority of labour market data illustrate a decline in employment in the sub-sectors under analysis. These developments are as expected. The apparent lack of coherence is discussed in further detail in the body of this article.

\section{Overview of the financial intermediation industry}

The financial industries are classified within Section J of the UK SIC. The industry is broken down into three main groups; financial intermediaries (Division 65), insurance and pension funds (Division 66) and financial auxiliaries (Division 67). Together they account for around 7 per cent of UK gross value added (GVA). A summary of the structure and data sources for these industries is presented in the Appendix.

Unlike most other industries, the Office for National Statistics (ONS) relies heavily on external data sources to measure the output of the financial sector. One of the 
key data suppliers is the Bank of England which supplies the bulk of the data used to measure Division 65. The majority of Division 66 uses data from the Association of British Insurers (ABI) - the trade association for the UK insurance industry. Division 67 relies on financial markets data, trade association data and some ONS data.

\section{- Division 65 financial intermediaries:}

consists of the activity of central banking, private banking, building societies and other financial intermediation. The first three components make up the majority of this sector with a large number of smaller financial intermediaries completing the picture. In total this division accounts for 4.4 per cent of Gross Domestic Product (GDP) and 63 per cent of Section J as a whole.

- Division 66 insurance and pension funds: consists of the activity of life insurance, pension funding and nonlife insurance. The first two components are of roughly equal size and make up just over half of the division, with nonlife insurance accounting for just under half (this component is dominated by motor vehicle insurance). In total this division accounts for 1.6 per cent of GDP and 23 per cent of Section J as a whole.

- Division 67 financial auxiliaries: covers the various financial auxiliaries which facilitate and administer financial markets by acting as agents for firms and governments within the economy. It consists of a large number of small specialists and accounts for 1.1 per cent of GDP and the final 14 per cent of Section J as a whole.

Each of these industries has been reviewed in the last few years as part of the Index of Services (IoS) Industry Review programme where various estimation issues have been considered. Further details on the improvements made are detailed within each section, as well as ongoing issues and difficulties in interpretation.

\section{Short-term measures - sources and methods}

Division 65 - financial intermediation, except insurance and pension funds Although SIC splits Division 65 by institutional type, the quarterly output measure of activity makes use of data based upon activity type. As such it is not possible to identify output for private banks, central banking and building societies individually. Instead ONS receives data for all three in aggregate, relating to directly measured activities (fees and commissions earnings) and indirectly measured activities (essentially the spread earnings on loans and deposits).

Directly measured activity currently accounts for just over a third of this division with indirectly measured activity (referred to as financial intermediation services indirectly measured or FISIM) accounting for the other two-thirds of activity (see Table 1). Prior to the Blue Book 2009 consistent quarterly estimates, there were measurement gaps within the division. The data now includes estimates for spread earnings on dealings activities and operating income from non-financial assets owned by these institutions which had previously been omitted. The inclusion of this data is as a result of joint work with the Bank of England and this working relationship will be important going forward.

\section{Fees and commissions}

Since the 2006 Blue Book, bank fees collected from the Bank of England Profit and Loss Survey have been used as the basis of output measurement for the directly measured element of banking. Two issues have been identified for further work. First is the forecasting (or nowcasting) of the series for the most recent periods, which ONS will take forward with the Bank of England once the time series are sufficiently long.

The second issue is deflation. As no specific deflator currently exists, the Average Earnings Index (AEI) for financial intermediation (excluding bonuses) is used. Work on improving price indices for the banking sector has been ongoing within ONS, and the results will be evaluated for use in the National Accounts.

When the fees series was introduced, the recommendation for deflation was to use the AEI for financial intermediation excluding bonuses, despite arguments by key customers that using the including bonuses series would be better. The use of the excluding bonuses series is justified on the following grounds:

\section{Table 1}

\section{Weight in Whole Economy Gross Value Added (GVA) per 1000 parts}

\begin{tabular}{lrrr}
\hline & FISIM & Direct & Total \\
\hline Banks and Building Societies & 25.8 & 12.0 & 37.8 \\
Other & 3.0 & 2.8 & 5.8 \\
Total & 28.2 & 14.8 & 43.6 \\
\hline
\end{tabular}

Source: ONS Blue Book
- the excluding bonuses series is a good proxy for the including bonuses series (due to the trends being similar)

- earnings including bonuses series are not included elsewhere in services (that is it maintains consistency)

- it could be argued that when pricing products banks base the trend of prices on expectations of normal wage payments and

- this is only a stop-gap series anyway - it is not the ideal solution and was an incremental improvement over the previous methodology of using employment data

\section{Financial intermediation services} indirectly measured (FISIM)

In the 2008 Blue Book, ONS introduced new methods for calculating the output of FISIM and allocating it to consuming sectors in line with European Council Regulations (see Box 1).

The new output method uses detailed data by sector on the interest charged on, and stocks of, loans and deposits. A volume measure is derived by deflating the stocks with the GDP expenditure implied deflator, excluding FISIM.

In terms of short-term measurement, although the new method is conceptually stronger, the data were only available quarterly initially, rather than the monthly availability for the old method, but work by the Bank of England has led to the provision of monthly stocks data which are used to calculate early volume estimates of FISIM. The monthly stocks data are used in a co-integration model to forecast FISIM for the Preliminary Estimate of GDP. They are fully available for the second data vintage which is the Output, Income and Expenditure estimate; thereby improving the quality of the early estimate of FISIM.

\section{Other financial intermediation}

Measurement issues in this sector relate to the factoring/invoice discounting and pawnbroker elements of other credit granting which are not captured by current data sources. Both of these sectors may be expected to pick up in volume terms during an economic downturn. As firms want to increase their cash holdings, in 


\section{Box 1}

FISIM

FISIM is an indirect measure of the value of services for which financial intermediaries do not charge explicitly. Financial intermediaries provide services for which explicit charges can be made, such as commission on foreign exchange, account charges and flat rate fees for overdrafts. However, financial intermediaries also rely extensively on revenue accruing from interest flows, paying or charging levels of interest that differ between lenders and borrowers. FISIM imputes direct charges for these services.
The allocation of FISIM is calculated as the difference between the effective rates of interest payable and receivable, and a 'reference' rate of interest considered to represent the risk free rate of lending/ borrowing. It was allocated across sectors from Blue Book 2008 onwards having previously been allocated to a nominal sector within the National Accounts. Between 1993 and 2004, FISIM added an average of 1.5 per cent to the level of GDP in chained volume measures (CVM). For examples of how FISIM is calculated and further information on the measurement of FISIM refer to Akritidis (2007). response to the restrictions in the supply of credit, the ability to sell on invoices even at a discount will be used by more firms. The demand for personal pawnbroker services is likely to increase as individuals lose jobs and job security. The volume of activity of pawnbrokers is not likely to be large, but the interest charged is often significant.

\section{Division 66 - Insurance companies and pension funds}

Volume measures for this division are obtained using quantity data, and not via deflation. The ABI publish volume data on a comprehensive range of life insurance and pension products. Data are published in September for the previous year and the periodicity is annual. Coverage is very good with about 96 per cent of the market (in terms of premiums paid) accounted for.

The ABI publish volume data for UK motor insurance. These are quarterly data with excellent coverage of insurance companies' exposure to risk. Their use avoids the problematic issue of deflation.

\section{Division 67 - Financial auxiliaries}

\section{Administration of financial markets (SIC 67.11)}

This group includes those financial exchanges that are based in the UK. At the time of the review, there were other exchanges (for example London Metals Exchange, Virt-X, International Petroleum Exchange) but given the dominance of the London Stock Exchange (LSE) and the London International Financial Futures and Options Exchange (LIFFE), it was decided to only measure these exchanges. However, new EU rules introduced in 2008 mean that the LSE no longer has a monopoly on share trading and there are a number of competitors (such as Chi-X and Turquoise among others). At present, there are no concerns with the coverage, but it is something that should be considered for the future.

\section{Fund management activities (SIC 67.12/1)}

This relates to Financial Services Authority (FSA) regulated funds, hence by definition excludes hedge funds. The bulk of funds under this heading belong to life insurance and pension funds:

- insurance - 39 per cent

- pension funds - 34 per cent

- retail - 14 per cent

- other - 9 per cent

- central banks/government - 2 per cent

- private clients - 1 per cent

A recent review introduced indicators for unit and investment trusts for retail funds as well as indicators for total financial assets of insurance and pension funds for institutional funds. While this will not be exhaustive, it does cover the main elements (87 per cent using the breakdown from the Investment Management Association (IMA)).

\section{Security broking and related activities (SIC 67.12/1)}

The exchange volume indicators serve a dual purpose within Division 67, as they are also used to proxy the output of the brokers and market makers. However, the problem with this approach is that UK-based dealers operate on exchanges throughout the world (notably the Eurobond market) and, as a consequence, may not reflect the true balance of activity.

Another issue is that over-the-counter (OTC) trading of financial instruments is not conducted through a central market, and is hence very difficult to measure.

ONS already collects data in this area via the Securities Dealers Inquiry. This form collects data on:

- profit/loss from dealing as a principal

- commissions

- interests and dividends

- other income

While the series are relevant the survey is subject to discontinuities and there are conceptual difficulties in deflation. At the time of the last review, the benefit of direct volume monthly exchange data was chosen in preference to the quarterly securities dealers' data. The survey is under development but the practical issues here will require much work and implementation of improvements is timetabled for Blue Book 2010 at the earliest.

\section{Activities auxiliary to financial intermediation not elsewhere classified (SIC 67.13) \\ This group covers the following:}

- independent financial advisers not specialising in insurance or pension funding advice

- mortgage brokers

- bureaux de change, foreign exchange brokers etc.

- hedge funds (on the basis that they are excluded elsewhere)

Financial advisers and mortgage brokers are companies that exist by earning commission from products they sell on to clients, usually households and businesses. They will include insurance, pensions, endowments, mortgages and so on. The commission is normally a percentage of the premiums paid by their clients. No data sources are currently available to measure this activity, and this is an area for future investigation.

There is no central foreign exchange market as trades are conducted between banks and brokers. Foreign exchange brokers earn their income by levying a percentage fee on any trades (net spread earnings). The Bank of England publishes a triennial survey of the foreign exchange (forex) market as part of an international survey for the Bank for International Settlements. Data should be split by spot, forward and options. The periodicity makes it unsuitable for quarterly or monthly use. 
Hedge funds are currently exempt from regulation and as such are not required to meet disclosure standards. It is estimated that hedge funds could account for up to 6 per cent of total fund management activity in the UK although recent trends are likely to have changed the balance of hedge fund activity somewhat. By definition, it is extremely difficult to derive a volume measure of output for these agents under the current regulatory framework.

The lack of transparency and data in this area makes development of reliable and complete indicators a difficult and prolonged process. A recent attempt to introduce PricewaterhouseCoopers ( $\mathrm{PwC}$ ) and Confederation of British Industry (CBI) joint data from their Financial Services Survey concluded that the data was not suitable for use as a volume indicator for the GDP output series.

Activities auxiliary to insurance and pension funding (SIC 67.2)

At present no indicators specific to this industry are used, instead the indicators used to measure insurance and pension funding are used as a proxy. Effectively this is assuming that broking has a fixed relationship with the insurance industry. No data sources are currently available to measure this activity and as such it is difficult to assess the validity of this assumption.

\section{Analysis of output and employment}

Having outlined and considered the measurement issues relating to short-term output indicators of financial activity, it is logical to consider their evolution against those of corresponding labour market data.

It is reasonable to expect that output and labour market data will move together, with an associated lag, during a sustained period of growth, or similarly through a prolonged downturn. The lag between the two sets of data might well reflect employers' perception of the permanency of a change in demand and the decision to either hire or lay-off workers.

This section examines the development in short-term output data and full and part time employment series for the subsectors of the financial intermediation and insurance and pension funding industries. Analysis of the activities auxiliary to finance will follow in future work.

\section{Employment data considerations}

The analyses presented in this article use the lowest level of disaggregation that will support investigation. Labour market data are taken from the LFS, which is a large household survey when considered in aggregate. It should be noted that sample sizes can be somewhat limited at a low sectoral breakdown, though will still be relatively robust for the larger components of the sector. As a consequence of small samples, data extracted at this level of detail can often be observed to be volatile but with no seasonal pattern. Non-seasonally adjusted data are therefore examined at this disaggregated level, although these data are often difficult to interpret in raw form due to a four week sample period affecting the raw data (leading to inconsistent timings across months of differing lengths). Despite difficulties with the rough dataset considered, the LFS is the best comparable series given the detail needed to consider the financial sector at the level in this article.

\section{Output data considerations}

In addition to all the measurement issues identified in the first part of this article, it is important to remember that the shortterm output measures used here are, in fact, designed to act as proxies for gross value added (GVA). Low level output (activity) indicators are weighted together by a value-added industrial breakdown of the UK economy. This approach assumes that in the short-run, changes in input (intermediate consumption) volumes move in tandem with changes in output volumes. This assumption is tested and corrected during the annual supply and use balancing process, but to the extent that it breaks down in recent periods, the growth in output may over or under state the growth in value added, and thus GDP.

\section{General comparison of direct and indirectly measured output for Division 65}

There are a number of factors underpinning the developments illustrated in Figure 1.
In relation to the directly measured output indicators, while the supply of credit has been hit by the credit crisis, non-risk prices, such as arrangement fees for mortgage and loan facilities have increased.

The relative stability in the indirect measure however, reflects a relative stability in the stock of deposits and loans. The stock of loans did not change dramatically through the year, as a result of restrictions on credit, while the stocks of deposits also remained constant as households continued to spend until the latter part of the year.

Given that the GVA data are built up using indicators of type of activity, rather than type of institution, it is not possible to derive separate GVA series for each of the banking, central banking and building societies sub-sectors. Instead, the direct and indirect data sets are weighted together by their share in overall output under National Accounts weights in order to produce a composite index for Division 65. Table 1 shows that the FISIM weight makes up over two-thirds of the overall composite, and the directly measured component (proxied by fees and commissions) one third. So, not surprisingly, the trend and movements in the FISIM series predominate.

This composite series has been used as a proxy for both the banks only and building societies only analyses below. This is necessary but does mean that marked differences in the performance of the subsectors may be masked in the composite series.

\section{Comparison of output and employment data}

\section{Banks}

The composite output series for banking, building societies and central banking shows a stable and increasing trend for activity throughout the period (see

Figure 2). The employment level for banks, although tracking output into 2007 (taking

\section{Figure 1}

\section{Output of FISIM and fees and commissions}

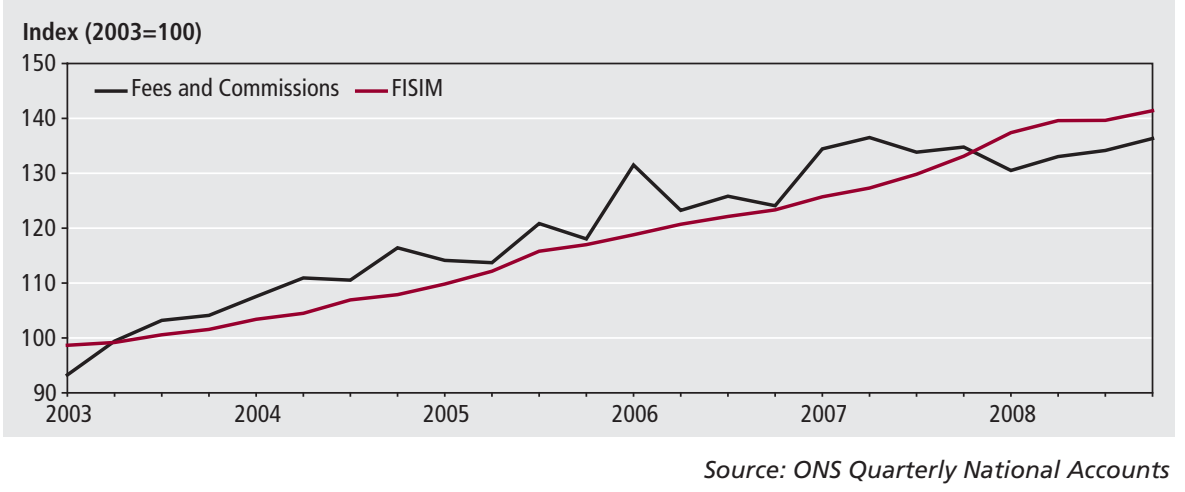




\section{Figure 2}

\section{Banks output and employment}

Employment in thousands

Index $(2003=100)$

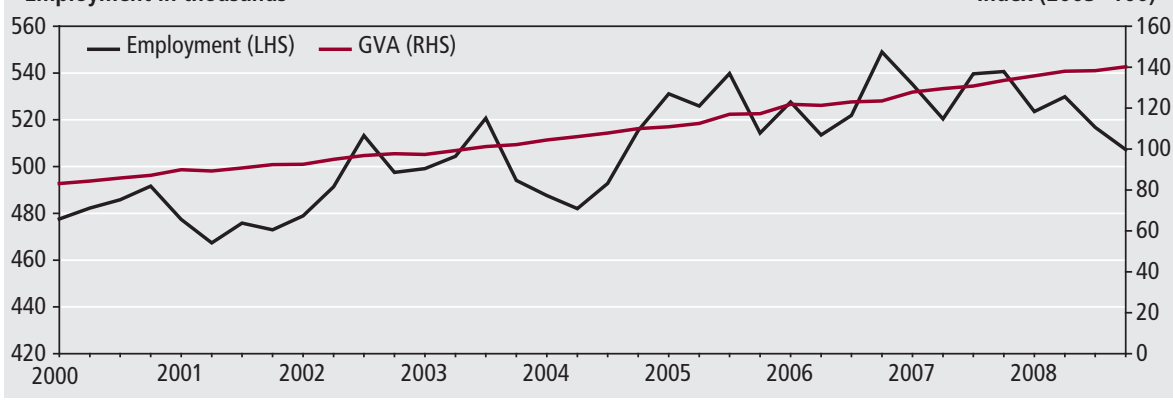

Source: ONS Quarterly National Accounts and Labour Force Survey

Figure 3

\section{Building societies output and employment}

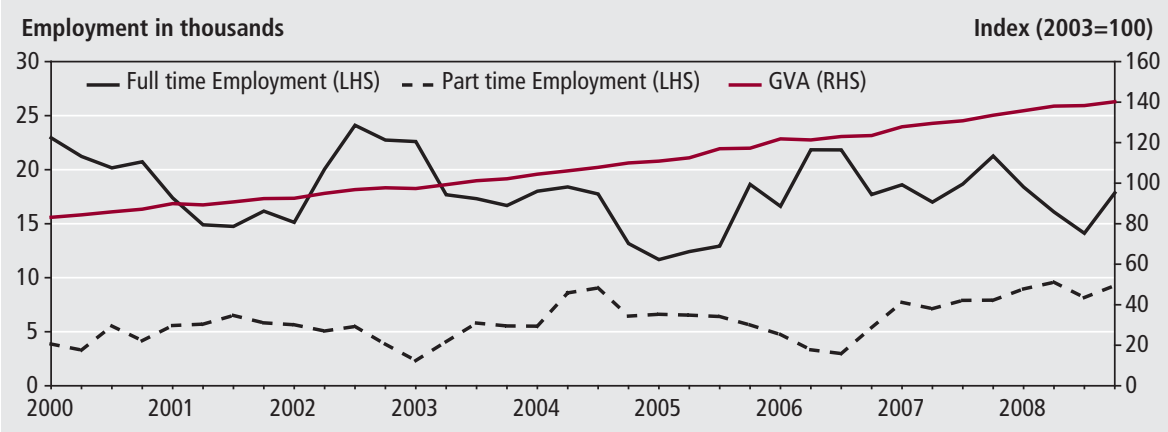

Source: ONS Quarterly National Accounts and Labour Force Survey

\section{Figure 4}

\section{Investment trusts output and employment}

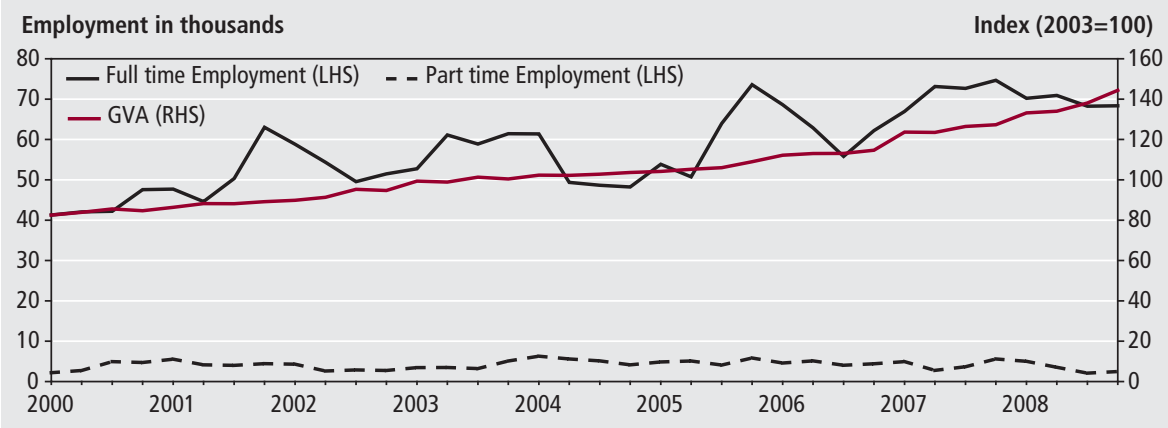

Source: ONS Quarterly National Accounts and Labour Force Survey

into account the volatility of non-seasonally adjusted data), has since fallen off quite steeply.

Given that employment is falling off as expected, the continued increase in output for the sector as a whole is somewhat surprising. The output measure we are analysing however is for banks, building societies and the central bank, and therefore may not to be representative of the output for the banking sector alone. It is quite possible that a fall in banking output might be offset to some extent by a smaller fall for building societies. Also, it has already been noted that this series is dominated by FISIM, which largely depends on the stock of loans and deposits, which have remained stable.
Both full and part-time employment have been substantially affected. The full-time employment level has fallen 4.8 per cent. Part-time employment has fallen more heavily: at the end of 2006 the employment level stood at around 103,000; this has fallen 19.6 per cent over the past two years and now stands at only just over 83,000 . This is in contrast to the trend for the economy as a whole, which has seen part-time employment increase over the period.

\section{Building societies}

Again, the composite output series for banking, building societies and central banking shows a stable and increasing trend for activity throughout the period, reflecting the stability of FISIM output (see Figure 3).

Employment, both full-time and parttime, has been volatile throughout the period however; this is potentially due to the sample sizes. The general trend for fulltime employment has been one of slight decline.

Throughout the last decade, part-time employment has seen a general upwards trend, and although this has levelled off slightly it still shows part-time employment increasing. The movement in part-time differs from the pattern in the banking sector, and is more in line with the economy as a whole. This indicates a pattern of substitution from full-time to part-time employment in this industry throughout the sample period.

\section{Investment trusts}

Both output and full-time employment have seen fairly steady growth over the period, with an increase in growth towards the end of 2008 (see Figure 4). This could be explained by the fact that, since the onset of the crisis, investment trusts are likely to have moved their funds from riskier assets to risk free assets. This would have generated large numbers of transactions, which consequently would have underpinned the growth in GVA for the sector.

The full-time employment level has fallen by around 8.5 percent over 2008. Part-time employment, which accounts for a much smaller proportion of employment in the industry, has declined at a noticeably faster rate than full-time employment, falling by around 50 per cent over 2008 as a whole, perhaps reflecting the lower costs of shedding such labour at a time of overall reduction.

\section{Life insurance}

Both full-time employment and output for life insurance have declined over the period 2000 to 2008 (see Figure 5).

Prior to the onset of the crisis there appears to have been a slight decline in the output of the life insurance sector. This is believed to be as a result of reduced take up of such insurance among first time home buyers unable to get on to the housing ladder.

Recent research by Life Insurance UK highlighted that people were cancelling their life insurance cover in order to save money to weather the recession.

Full-time employment levels have tended to track the slight decline in output and 


\section{Figure 5}

\section{Life insurance output and employment}

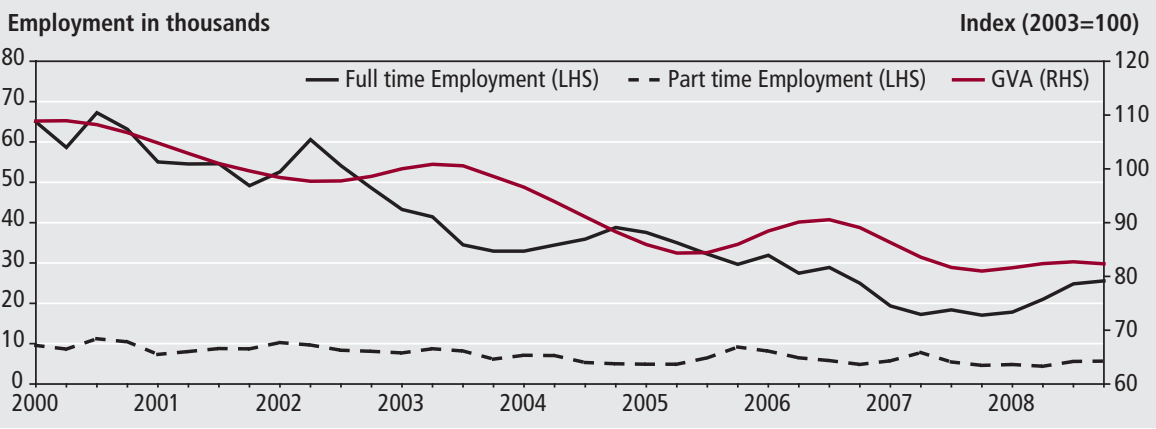

Source: ONS Quarterly National Accounts and Labour Force Survey

\section{Figure 6}

\section{Non-life insurance output and employment}

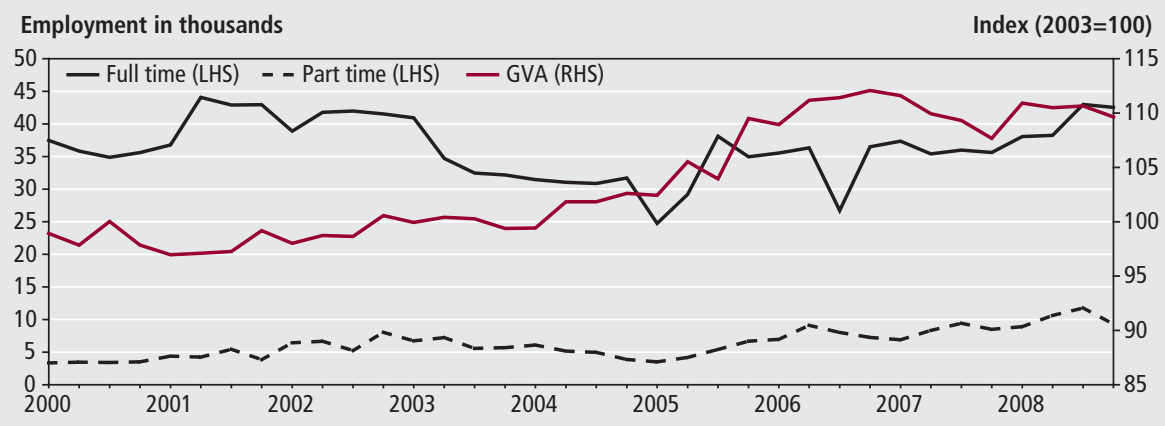

Source: ONS Quarterly National Accounts and Labour Force Survey

\section{Figure 7}

\section{Pension funding output and employment}

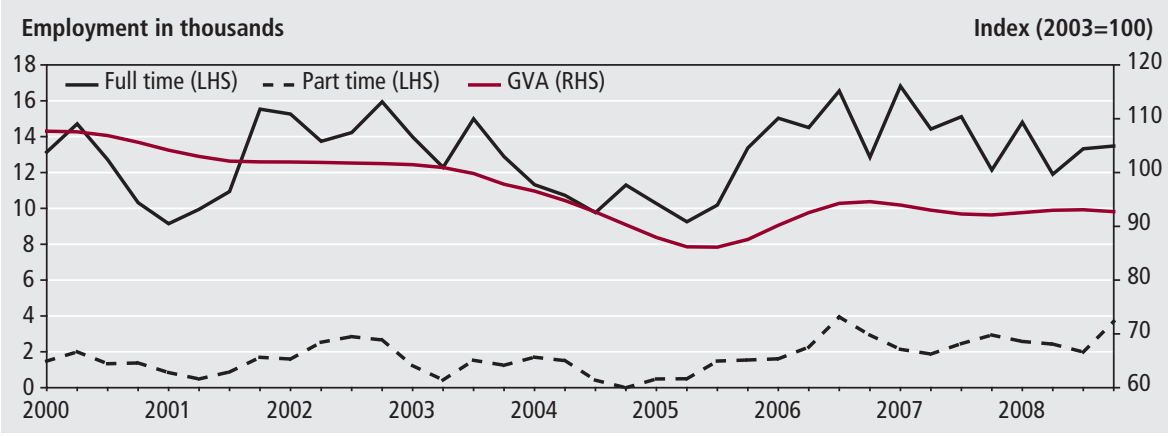

Source: ONS Quarterly National Accounts and Labour Force Survey

this is thought to be as a result of the strong competition in the sector (supermarket banks have entered this sector aggressively), which means that prices and costs have needed to be kept under control.

In short, the output indicators for this sector appear to be appropriate in terms of coherence and expectations.

\section{Non-life insurance}

Over the past decade, the output data for non-life insurance has been slightly more volatile than for life insurance and pension funding (see Figure 6). The data does however, show a general upward trend. For the period up to late 2005 the data shows gradual growth. However, the final quarter of 2005 saw a substantial jump, followed by the same trend of slow growth.

The most significant component of non-life insurance is motor insurance: a necessity for those that drive cars, leading to low variability in demand, given income. This means that during the current economic crisis we would expect to see little change in the level of output for nonlife insurers, and any negative change that we do see should be related to an overall weakening in transport demand.

Full-time employment over the whole period has fluctuated about a broadly stable level. Part-time employment has had a general trend of growth over the whole period, with marked growth since the beginning of 2005. Thus the activity indicators for non-life insurance appear to be coherent.

\section{Pension funding}

The output of the pension industry over the past decade can be split into three distinct phases (see Figure 7). The first, from 2000 to mid-2005, was a phase of decline with around a 20 per cent fall in the index from 2000 Q1 to 2005 Q3. The second phase is of growth between mid-2005 and late 2006 . The final phase is of neither growth nor decline, with the index fluctuating by less than 2 per cent over this period.

The developments in the output activity of the pension funding industry are consistent with a number of factors including both legislative and of corporate sector performance. The fluctuations in both employment and output around 2004 can be mainly attributed to the implementation of the Pension Act (2004), and subsequently the Pension Protection Fund in 2005.

The decline in output prior to 2004 is a consequence of lax rules prior to the introduction of these regulations. Since then, the output in pension funding has grown in line with legislative requirements and strong corporate profits, which have both ensured that the 'funding gap' has started to close.

During times of recession the output of pension funding might be expected to fall in line with employment. Up to the end of 2008 , however, this is not what we have observed. Output of the pension funding industry remained fairly flat through the second half of 2008, with a slight reduction into $2008 \mathrm{Q} 4$. One of the main reasons behind this development could be attributed to the lag between changes in economic output and the labour market. There had been little reduction in the level of employment going into 2008 Q4 and therefore there can be little expectation that pension funding output will have been impacted significantly. With large reductions in LFS and WFJ employment into 2009 Q1, it would be reasonable to assume that pension funding output would have fallen similarly.

Based on this conjecture, the activity indicators for pension funding appear to be appropriate in terms of coherence and expectations.

\section{Conclusions}

Measuring the activity or output of the financial sector is extremely challenging, both conceptually in how to define a unit 
of output of insurance or banking services, and practically. These challenges were discussed in the section on the analysis of output and employment, where little coherence between output indicators and labour market data for both the banks and building societies and the investment trusts sectors was observed. Part of the reason behind this lack of coherence can be attributed to measurement issues surrounding the growth in recent years of special purpose vehicles, unregulated institutions such as hedge funds and the shadow banking sector in general.

We should also consider the unadjusted nature of the labour market data used in this preliminary analysis, although the data does cover the whole of the sector whereas the National Accounts aggregates are subject to limitations. These limitations and other financial sector measurement issues are discussed further in the article on corporate sector balance sheets in this edition of Economic and Labour Market Review.

ONS has been working with the Bank of England for some time to try to improve both coverage and relevance of the indicators used in the calculation of shortterm GDP, and this work continues. The main development areas currently being pursued are:

- the introduction of indicators for net spread earnings and other income
- to review the use of the AEI excluding bonuses to deflate fees and commission, and to potentially replace it with PPI and RPI components, and

- to investigate all possible data sources for financial auxiliaries, including hedge funds

\section{CONTACT}

凶)elmr@ons.gsi.gov.uk

\section{REFERENCES}

Akritidis L, (2007) 'Improving the measurement of banking services in the UK National Accounts', Economic and Labour Market Review, May 2007. 


\section{APPENDIX}

Table A1

Financial services (Sector J): sources, indicators, weights (2003) and deflators

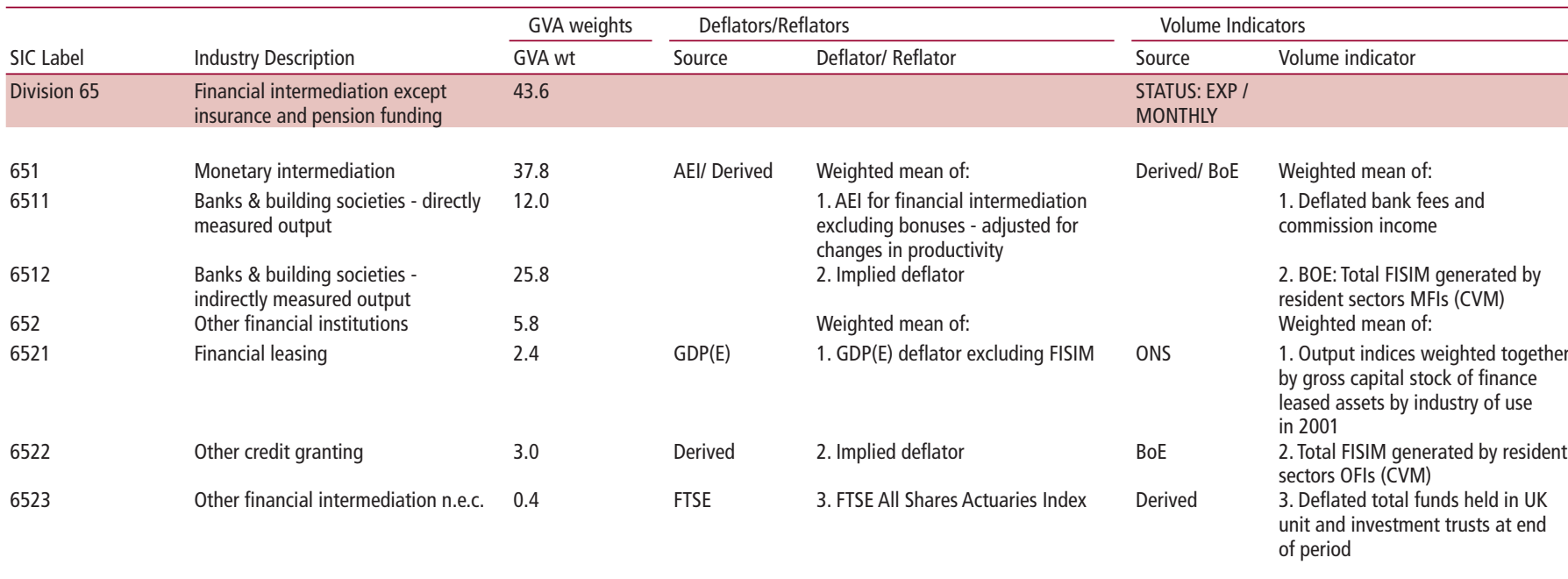

\begin{tabular}{|c|c|c|c|c|c|c|}
\hline Division 66 & $\begin{array}{l}\text { Insurance and pension funding, } \\
\text { except compulsory social security }\end{array}$ & 16.3 & & & $\begin{array}{l}\text { STATUS: EXP / } \\
\text { ANNUALLY }\end{array}$ & \\
\hline 6601 & Life insurance & 4.3 & Derived & Implied deflator & $A B I$ & $\begin{array}{l}\text { Weighted mean of industrial, } \\
\text { individual and group policies }\end{array}$ \\
\hline 6602 & Pension funding & 4.6 & Derived & Implied deflator & $A B I$ & $\begin{array}{l}\text { Weighted mean of annuities, } \\
\text { individual, defined benefit/ } \\
\text { contribution and other pension } \\
\text { schemes. }\end{array}$ \\
\hline 6603/01 & $\begin{array}{l}\text { Non-life insurance - UK motor } \\
\text { insurance }\end{array}$ & 7.4 & Derived/ GDP(E) & 1. Implied deflator & $A B I$ & $\begin{array}{l}\text { Weighted mean of comprehensive, } \\
\text { non-comprehensive, other vehicles } \\
\text { and motor cycles exposure }\end{array}$ \\
\hline $6603 / 02$ & Non-life insurance - other & & & 2. GDP(E) Implied deflator & ONS & $\begin{array}{l}\text { Volume of non-life insurance } \\
\text { output: Provisions adjusted for } \\
\text { claims }\end{array}$ \\
\hline Division 67 & $\begin{array}{l}\text { Activities auxiliary to financial } \\
\text { intermediation }\end{array}$ & 10.5 & & & $\begin{array}{l}\text { STATUS: EXP / } \\
\text { ANNUALLY }\end{array}$ & \\
\hline \multirow[t]{6}{*}{6700} & $\begin{array}{l}\text { Activities auxiliary to financial } \\
\text { intermediation }\end{array}$ & 10.5 & & Weighted mean of: & & Weighted mean of: \\
\hline & & & $\mathrm{AEI}$ & $\begin{array}{l}\text { AEl for financial intermediation } \\
\text { excluding bonuses - adjusted for } \\
\text { changes in productivity }\end{array}$ & LSE & $\begin{array}{l}\text { British government securities, and } \\
\text { stock exchange transactions }\end{array}$ \\
\hline & & & $\mathrm{AEI}$ & $\begin{array}{l}\text { AEI for financial intermediation } \\
\text { excluding bonuses - adjusted for } \\
\text { changes in productivity }\end{array}$ & LIFFE & Derivatives transactions \\
\hline & & & FTSE & FTSE All Shares Actuaries Index & Derived & $\begin{array}{l}\text { Deflated total funds held in UK unit } \\
\text { and investment trusts and financial } \\
\text { assets of insurance and pension } \\
\text { funds at end of period }\end{array}$ \\
\hline & & & $\mathrm{AEI}$ & $\begin{array}{l}\text { AEl for financial intermediation } \\
\text { excluding bonuses - adjusted for } \\
\text { changes in productivity }\end{array}$ & $A B I$ & $\begin{array}{l}\text { Life insurance policies, income } \\
\text { protection, annuities, pensions and } \\
\text { non-life insurance exposure. }\end{array}$ \\
\hline & & & $\mathrm{GDP}(\mathrm{E})$ & GDP(E) implied deflator & ONS & $\begin{array}{l}\text { Volume of non-life insurance } \\
\text { output: provisions adjusted for } \\
\text { claims }\end{array}$ \\
\hline
\end{tabular}

\section{Notes:}

Source: ONS (for full version see Blue Book 2008)

1 BoE - Bank of England; IMA - Investment Management Association; AIC - Association of Investment companies; AEI - Average Earnings Index; FTSE -

Financial Times Stock exchange; GDP (E) - Gross Domestic Product (Expenditure); MFI - Monetary Financial Institutions; OFI - Other Financial Institutions;

NTPS - Non-Trading Public Sector; CVM - Chained Volume Measures; ONS - ONS quarterly inquiry; ABI - Association of British Insurers. 